\title{
Community Perceptions on Schistosomiasis in Northeast Brazil
}

\begin{abstract}
Andressa Isabela Ferreira da Silva, ${ }^{1}$ Selma Patrícia Diniz Cantanhede,${ }^{2}$ Jessica Oliveira Sousa, ${ }^{1}$ Renata Martins Lima, ${ }^{1}$ Nêuton Silva-Souza, ${ }^{3}$ Raimunda Nonata Fortes Carvalho-Neta, ${ }^{4}$ Zafira da Silva de Almeida, ${ }^{5}$ Débora Martins Silva Santos, ${ }^{6}$ Alcina Vieira de Carvalho Neta, ${ }^{7}$ Ilka Márcia Ribeiro de Souza Serra, ${ }^{8}$ and Lígia Tchaicka ${ }^{2 *}$

${ }^{1}$ Departamento de Biologia, Universidade Estadual do Maranhão, São Luís, Brazil; ${ }^{2}$ Departamento de Biologia, Laboratório de Biodiversidade Molecular, Programa de Pós-Graduação em Recursos Aquáticos e Pesca, Universidade Estadual do Maranhão, São Luís, Brazil; ${ }^{3}$ Departamento de Biologia, Laboratório de Parasitologia Humana, Universidade Estadual do Maranhão, São Luís, Brazil; ${ }^{4}$ Departamento de Biologia, Laboratório de Biomarcadores em Organismos Aquáticos, Programa de Pós-Graduação em Recursos Aquáticos e Pesca, Universidade Estadual do Maranhão, São Luís, Brazil; ' 5 Laboratório de Pesca e Ecologia Aquática-LabPEA, Programa de Pós-Graduação em Recursos Aquáticos e Pesca, Universidade Estadual do Maranhão, São Luís, Brazil; ${ }^{6}$ Departamento de Biologia, Laboratório de Morfofisiologia Animal, Programa de PósGraduação em Recursos Aquáticos e Pesca, Universidade Estadual do Maranhão, São Luís, Brazil; ${ }^{7}$ Laboratório de Patologia Molecular- LPMol, Programa de Pós-Graduação em Ciência Animal, Universidade Estadual do Maranhão, São Luís, Brazil; ${ }^{8}$ Departamento de Biologia, Programa de Pós-Graduação em Recursos Aquáticos e Pesca, Universidade Estadual do Maranhão, São Luís, Brazil
\end{abstract}

\begin{abstract}
Schistosomiasis is a serious public health issue in the world infecting more than 200 million people. In Maranhão state, Brazil, the disease has a high prevalence in the Baixada Maranhense microregion, where the socioeconomic conditions, high prevalence of freshwater snails, elevated incidence of human infection, and large rodent populations make the area highly conducive to the life cycle and persistence of schistosomiasis. The objective of this study was to record the perception of residents and health/public education professionals regarding this parasitosis and also understand their knowledge of the relationship between schistosomiasis and the environment. We conducted 53 interviews addressing the socioeconomic, behavioral, and environmental issues surrounding schistosomiasis. It was recorded that the population believed the environment is the main cause of the disease and the fisherman may be stigmatized by their chance of having the disease. Health/public educational professionals in the region indicated that there were no regular educational campaigns, which contributed to the high rates of reinfection and the difficulties in preventing and controlling the spread of the disease. These data clearly demonstrate the need for interdisciplinary work that engages the community in gathering and disseminating knowledge and developing solutions to minimize the occurrence of this major health issue in the region.
\end{abstract}

\section{INTRODUCTION}

Schistosomiasis is a neglected tropical disease caused by a chronic infection with parasitic helminths of the genus Schistosoma. ${ }^{1,2}$ Five species of trematode infect humans, causing intestinal or urogenital schistosomiasis. ${ }^{2,3}$

Even with schistosomiasis eradication strategies worldwide, this parasitosis remains a major public health problem. $^{1,4}$ It is the second most prevalent tropical disease after malaria and affects 240 million people in 78 countries worldwide. $^{2}$

In Brazil, this disease is known as "water's belly" or "snail's disease" and is caused by Schistosoma mansoni (Sambon, 1907). ${ }^{5}$ In this country, it is estimated that approximately 6 million of people are infected with schistosomiasis and that 25 million people live in areas at risk for contracting. ${ }^{6,7}$ Since the 1970s, Brazil has a "Schistosomiasis Control Program"; however, the number of cases is still very significant in the northeast and southeast regions, occurring in 19 states, among them, in Maranhão. 5,6

Schistosomiasis has been reported in Maranhão since $1920 .^{9,10}$ The areas of the coast and the Baixada Maranhense have a higher prevalence. ${ }^{10}$ The Baixada Maranhense microregion presents the largest set of seasonal lacustrine basins in the northeast known as flood fields. ${ }^{11}$ These waters harbor populations of snails (vectors) and are used by the human population that performs daily activities (fishing, farming,

*Address correspondence to Lígia Tchaicka, Departamento de Biologia, Laboratório de Biodiversidade Molecular, Programa de Pós-Graduação em Recursos Aquáticos e Pesca, Universidade Estadual do Maranhão, Cidade Universitária Paulo VI, s/n, Tirirical, São Luís 65055-970, Brazil. E-mail: Itchaicka@yahoo.com.br entertainment, and others) having contact with S. mansoni larvae. ${ }^{9,12}$ In addition, flooded fields harbor Holochilus sciureus (Wagner, 1842), a semi-aquatic rodent that act as the definitive host of $S$. mansoni, increasing the life cycle opportunities for the parasite..$^{9,13,14}$

There is a large amount of research available on epidemiology and control of schistosomiasis, part of what was carried out in Baixada Maranhense, investigating questions about snails and/or rodents. ${ }^{13-16}$ On the other hand, studies on the perception of people living in areas at risk of transmission are more limited. The importance of understanding schistosomiasis is recognized by many scholars, but social issues are not much investigated. ${ }^{17}$

Understanding people's level of knowledge about schistosomiasis is important for treatment and to direct health education actions to promote disease prevention attitudes. ${ }^{18,19}$ Schistosomiasis eradication programs are more successful when using integrated control measures, including health education and popular participation. ${ }^{20-23}$

Based on the aforementioned premises, the objective of this study was to understand the perceptions of schistosomiasis among residents of São Bento, one of the poorest cities in the Baixada Maranhense. We also analyzed the role of health education in this context.

\section{METHODS}

Study area. The study was carried out in the municipality of São Bento, located in the Baixada Maranhense microregion (Maranhão, Brazil), an area with vegetation composed of large flooded fields. São Bento has 45,560 inhabitants and an area of $468,892 \mathrm{~km}^{2}$. $^{24}$ Three districts of São Bento (Outro Banda, Porto Grande, and São Judas) were selected for the study 
because of its high prevalence of infections by $S$. mansoni. The region's economy is based on artisanal fishing, agriculture, livestock, and trade. Housing and basic sanitation are precarious.

Study design. This was a qualitative study of the descriptive and exploratory type $e^{25,26}$ carried out with the residents of the selected districts and health/education employees who worked in the districts. The interviewee should agree to participate in the survey and be 18 years of age or older. It was made clear to the study population that participation in the research would be voluntary and that people could refuse or withdraw their consent at any stage of the research.

Study participants were selected based on their residency in one of the three selected regions for more than 1 year. These requirements assured us that the participants are more likely to be familiar with the regions and the issues surrounding schistosomiasis. We visited the residents at home to interview (head of the family or another family member who met the inclusion criteria). For employees, the interview took place at work institutions (Municipal Health Department and two municipal schools). Interviews were conducted from August to November 2013 using scripts (open and closed questions) prepared by the authors and previously tested in an area with similar socioeconomic characteristics. The environmental characterization was recorded through in loco observations made by the researchers and completed by the responses of the residents in relation to types of housing, basic sanitation, and the use of the environment.

In the first stage, sociodemographic characteristics (age, gender, schooling level, and professional occupation) of residents were investigated. We also used a semi-structured script to investigate the perception of the residents about schistosomiasis (relationship between schistosomiasis and "water belly," transmission and symptoms of schistosomiasis, and whether the parasitosis was a reality in the municipality).

To carry out our research with the municipal employees, we conducted a semi-structured script interview investigating the occurrence of schistosomiasis in the districts and the activities that the institutions performed to avoid or reduce the cases of the disease in those localities. The scripts used as tools to obtain data in the interviews were prepared by the authors of this research and had open and closed questions to collect statement of the interviewee. These scripts have not yet been published, but they have previously been tested in an area with similar socioeconomic characteristics to the study site.

All the interviews lasted on an average of 30 minutes and were performed in Portuguese and recorded on a portable recorder. The answers were transcribed in full in Word 2013 software in the same language. For the dissemination of the results of this article, the citations were translated into English by a company specialized in translation and proofreading services.

Data analysis. The interviews were submitted to content thematic analysis. ${ }^{27}$ Data coding was performed by two researchers in this article. The discourses were analyzed through a set of techniques that allows inferences to be made from the objective content of people's speeches. Opinions that were frequently expressed, dissent, and consensus were considered, being constituted in registration units. From the exhaustive reading of the instruments, pre-analysis was performed, which consisted in choice of reports, formulation of hypotheses, and elaboration of indicators to support interpretation. Then, there was the exploration of the material where there were elaborated groupings and associations related to the objectives of the study, from which emerged categories. The initial categories were elaborated from the first impressions about the investigated reality. Excerpts were selected based on the interviewees' narratives and the theoretical framework. To refine the analysis of the data, the progressive grouping of initial categories resulted in the appearance of the intermediate categories that consequently supported the construction of the final categories. Finally, the data were processed (inferences and interpretation of the results found). ${ }^{28}$ To manage conflicts, we sought to understand the subject's thinking through the content expressed in the text. Technical neutrality was also adopted through a distancing relationship between the researcher and his object of analysis.

Ethical considerations. The procedure was in accordance with the ethical standards of the committee on human experimentation, the Committee of Ethics in Research of Universidade CEUMA is linked to the National Commission of Ethics in Research. Written consent was obtained from all subjects, and this study was approved under the protocol number CEP: 06/10. A code was used to ensure participants' anonymity. Interviewee citations were identified by the letters "E" followed by a number indicative of the order of interviews for the distinction of the participants.

\section{RESULTS}

Study characteristics: area, population, and sociodemographic information. The study area had a total of 53 households: 21 houses in Outra Banda, 14 houses in Porto Grande, and 18 houses in São Judas. Only five of these domiciles did not participate in our research (two located in the district Outra Banda, two of Porto Grande, and one of São Judas). Even with the scheduled interviews and three tentative scheduling, researchers were not seen in three households, in this way, the three heads of families (or representative). On the other two households, we were informed that they consisted of abandoned houses.

A total of 48 households were sampled, and the number of inhabitants per residence ranged from three to five people. Thus, 48 residents (heads of household or representatives) were interviewed: 27 men aged between 23 and 74 years and 21 women aged between 21 and 63 years.

Most of the people had only completed elementary education (19 men and 11 women), few completed high school (five men and six women) or higher education (two men and three women). There was an illiterate man and a woman who had a technical level of education.

Respondents reported fishing in temporary lakes (known as "flood fields") as their main occupational activity. Breeding of animals (cows, buffaloes, and pigs) was the second professional occupation cited. Fishing has been reported as an activity performed by men, women, and children.

Five workers from municipal institutions were interviewed: one representative of the Municipal Health Department and four representatives of educational institutions (teachers from schools of the districts). All municipal workers had higher education, and the age-group ranged from 29 to 55 years. Only one worker was male (representative of the Municipal Health Department). 
Environmental characterization. All respondents answered that their homes were masonry covered with roof tiles. The interviews revealed that the houses had few rooms (from three to four compartments at most). Only three houses did not have septic tank for defecation. However, some participants reported the use of the backyard for feces evacuation.

The residents said that there was no sewage collection system in São Bento, and they said that all sewage wastes were dumped in the streets. In addition, they pointed out that there is frequent outflow of hospital sewage in domestic backyards. On the situation of the hospital sewer, a resident stated that

This water flows from the hospital to the countryside; it is dirty. I have already denounced it many times. I have spoken a lot to the people there: make a tank; this water runs from the hospital; this is dirty water. I mean, a woman has a child ... she gives birth, right? This water, the washing water, runs here from the hospital, as well as other water. I think. It causes all this. Right? (E1)

Water supply and disposal of household waste were other environmental characteristics commented by the residents. They all said that their residences had piped water coming from wells that were built through public funding. The interviewees stated that there was no domestic waste collection service. Some of them said they dumped trash on abandoned land, whereas others reported that they burned or buried household waste in their own backyard.

"In the other day I buried the trash in the yard. There are days when I set the whole trash on fire... Another day there was no way and I threw it all on the empty ground. It was a lot of trash and I threw it there. Everyone leaves trash on that ground" (E17)

The streets near the houses we visited had no pavement, and all of them had streams of sewage flowing outdoors into the flooded fields. We observed that most of the houses were built on small pieces of land in the flooded fields.

It was possible to see the villagers fishing in flooded fields and also to notice the frequent presence of women washing dishes and clothes and children playing in the lake water. These observations show the existence of an intimate relationship between the residents and the environment in which they live.

Perceptions about schistosomiasis. The information provided by residents were organized in categories that emerged from main ideas expressed in the answers. We retrieved four categories (for detailed analysis, see Supplemental Tables 1-5).

Schistosomiasis or "water belly.". Respondents were asked if they knew about schistosomiasis or water belly and if the two names referred to the same disease. Supplemental Table 2 shows the subcategories produced. Most people do not know the clinical name schistosomiasis, but all recognize its popular name; the few who knew both terms did not recognize them as the same disease.

To understand which other diseases could be confused with water belly, interviewees were asked about the symptoms of water belly. The symptoms were easily confused with other parasites, and the only symptom seen as definitive was abdominal enlargement:

His belly had grown, his foot was swollen, and he was in a lot of pain [...] (E6)

\section{[...] his belly was very swollen, right ... well, grown. (E7)}

He feels very weary ... his belly is swollen, it's getting huge. (E10)

Disease and environment. This category was elaborated from the answers to the following question: "Do you think this disease occurs in your city?" To this question, the interviewees expressed that "the water belly is part of everyday life." We present the subcategories produced and the interviewees' statements in Supplemental Table 3.

Problems with basic sanitation, verified in the environmental evaluation, were also mentioned by the residents in discourses that associated them with the category of "schistosomiasis and environment" analysis. The lack of basic sanitation is recognized as a problem and criticized by some residents. Despite this criticism of sewage dumping in their neighborhood and its relationship with schistosomiasis, many respondents referred to schistosomiasis as "a disease of the men from the field," that is, they did not recognize themselves as elements of the cycle of transmission of the disease or as individuals who are at risk of contamination, saying "No, not here in this neighborhood. Here, no." (E3)

Cycle and contagion. Trying to understand why people do not recognize themselves as being a cause for the spread of the disease, despite recognizing the high prevalence of disease and its relationship with the lack of basic sanitation, they were asked how the disease was contracted. Analysis of the responses produced four subcategories and their respective speeches (Supplemental Table 4).

There is some knowledge about the disease cycle but some confusion too. Many attribute contagions directly to snails, E1 and $E 10$ also included fish, whereas $E 8$ closely described the cycle reported in the scientific literature, explaining the role of "microbes," which would be equivalent to cercariae in the schistosomiasis cycle.

The understanding of contagion is also reflected in the answers obtained to the question: "What is the behavior of people who had the disease cured to prevent further contagion?" These responses reinforce the idea that the natural environment is the cause of illness because they report people have no option, they need to continue fishing. Most people treat the disease with drugs, thinking that the medicines will make possible "not to get the disease anymore." This idea creates a cycle in which the person is infected and reinfected shortly after.

Perceptions of municipal health/education employees. The districts investigated are nearby, and most children study at two schools located in Outra Banda (nursery and elementary schools). From these schools, we listened to four teachers. About the cases of students with schistosomiasis, only one respondent reported that there is a suspecting case of schistosomiasis. One of the participants said, "No report. 
Even because they have not passed through here to kid "stuff" (exam) (E11)." The teacher is referring to the Municipal Health Service that has the obligation to monitor this kind of diseases, according to the Brazilian health system. Thus, education professionals understand that the control of schistosomiasis is the responsibility of the health service. When we asked what the school's actions would be in the face of a possible case of schistosomiasis, the speeches referred to the treatment performed by the health department: "This is with the health department. Who give medicine." (E14). Schools do not carry out educational activities or campaigns on schistosomiasis, according to the teachers.

The health professional interviewed was the head of schistosomiasis control plan in São Bento. He recorded in the interview that positive diagnosis for schistosomiasis in the studied districts was common in recent years. In the current year (during the study period), the health service was not monitoring the locations because of the rainy season, which makes access difficult. About the disease control actions, our interviewee reported the existence of an annual planning and highlighted the treatment with the use of medication to treat sick people.

We observed in a spontaneous comment that this health professional does not believe in the health education process: "We do not take preventive actions at school. But it often does not help: you will talk with students, so they will talk to their parents; but sometimes it's hard, you know? Then you will have to gradually develop awareness among their parents, but it's as I said to you before: if he stops fishing and hunting, they will starve to death - he and his family." (E13)

Another spontaneous comment from the health professional referred to the form of transmission of schistosomiasis in São Bento. The interviewee spoke about the lack of job opportunities in the municipality and the consequent transmission of schistosomiasis related to occupational activities:"But because sometimes people come and ask, "why do I have schistosome every time I do the test?," it is very easy to say to people here, "because here, more than $80 \%$ of the population of São Bento lives by hunting and fishing. If he stopped going to the field, he would not be infected anymore. If he could have a job inside, with an air conditioner, sitting in a soft chair, he would never have schistosome. But how does he not go the field? ... If he didn't go to the field, his own family would leave ... would die of starvation, he will have to hunt and fish."(E13)

\section{DISCUSSION}

People from São Bento live in houses and streets that have basic sanitation problems, and some of these problems are perceived by then. Basic sanitation data recorded in the last Brazilian census had already showed deficiencies in these social indicators in São Bento, a city where only $6 \%$ of residences have adequate sanitation. ${ }^{24}$ Deficiencies in basic sanitation were identified as factors related to the occurrence of geohelmintosis and schistosomiasis in rural areas of Kenya, ${ }^{29}$ Nigéria, ${ }^{30,31}$ and also in Minas Gerais in Brazil. ${ }^{28,32}$

The form of human occupation of the space coupled with inadequate housing conditions helps the spread of schistosomiasis in urbanized areas. ${ }^{33-35}$ This spatial disorganization is noticed in the more urban areas of Sao Bento where some "flooded fields" enter the backyards of the houses.
On the other hand, the perception of residents reveals that they understand the natural environment, and not the urban area, as the main cause of schistosomiasis. There is no doubt about the importance of this relationship between man and the swamp flooded in the maintenance of the disease, as people fish and perform domestic activities in the swamps. Research conducted in Brazil ${ }^{28,32,36,37}$ and Africa ${ }^{29-31}$ shows that contact with water for leisure, agriculture, fishing, and personal hygiene activities are determining factors for the increase in the prevalence of schistosomiasis. However, their perception brings the idea of schistosomiasis as "disease of the man from the field," which can create a stigmatization of rural workers, fishermen, and hunters, which represent most of occupation of people in the region.

As such, it is necessary to value "the man of the field" as a way to improve the self-esteem of the residents because the local population is composed mainly of fishermen (as indicated in the environmental assessment). It is also important that each individual recognize and accept their close relationship with the "flooded fields." It is important to remember that in addition to harboring a variety of species (some vulnerable), this ecosystem has potential for ecotourism and is the source of livelihood for the local population. ${ }^{38}$

The stigma attributed to the sick man living in rural areas is responsible for increased feelings of fear and shame, causing impacts such as reduction of search for appropriate treatment for parasitic diseases. ${ }^{29}$ About schistosomiasis, the stigmatization of this man is very worrisome because some studies indicate that the predominance of cases of the disease is related to the male gender. ${ }^{35,37,39}$ Culturally, men are not in the habit of seeking medical care because they are known as "strongest individuals." However, when vulnerable individuals (fishermen, for example) do not seek the health service for proper diagnosis and treatment, this may favor the occurrence of severe forms of schistosomiasis and may also help maintain outbreaks of the disease by means of asymptomatic individuals with low parasitic load. ${ }^{40}$

The stigmatization process can cause different behaviors in individuals when facing schistosomiasis symptoms. There may be recognition of the severity of the disease where the individual cares, but stigma prevents care. In addition, denial leads individuals to ignore symptoms and complications of parasitosis. ${ }^{41}$ Thus, people may not recognize their participation in the cycle of transmission of schistosomiasis.

As an example, studies have revealed that people blame the environment and the snail and ignore human interference in the process of transmitting schistosomiasis. ${ }^{42,43} \mathrm{We}$ observed this behavior in our research, and we believe that it reflects a naive and reductionist environmental perception or even the lack of confidence and inability to prevent the transmission of schistosomiasis.

Stigmatization compromises quality of life and increases social exclusion. ${ }^{44}$ For these reasons, it is very important to know how people perceive the diseases to ensure effective strategies for prevention and control of these parasites. ${ }^{20}$ Environmental education, in turn, is an important tool for the process of reflection and reconstruction of knowledge. ${ }^{45}$

The interviewees' lack of knowledge about the word schistosomiasis as the name of the disease is similar to what happens in other endemic areas. Investigations conducted in an informal urban settlement in Kenya ${ }^{46}$ revealed that most participants in this study reported not knowing much about 
the disease but heard about schistosomiasis in school and some said they had never heard about. Discrepancies on the knowledge of schistosomiasis were also noted in the study conducted in Swaziland (where there is a simultaneous occurrence of Schistosoma haematobium and S. mansoni ${ }^{47}$ ). In this study, most participants heard about schistosomiasis. However, most of them knew about urinary schistosomiasis, and only one individual knew about abdominal schistosomiasis. In Brazil, studies conducted in endemic rural areas of Minas Gerais revealed children and teachers with previous knowledge about schistosomiasis recognizing the disease by the popular name ${ }^{28}$ and also children who had never heard of schistosomiasis. ${ }^{48}$ It is an important fact to be considered in the education campaigns.

On the symptoms of schistosomiasis, our results showed that respondents perceive symptoms that are not unique to schistosomiasis. Stomach pains, diarrhea, and bloody stools have been reported in studies evaluating people's perception of schistosomiasis. ${ }^{28,49}$ These gastrointestinal problems and also other symptoms (headache, dizziness, weakness, fever, and white patches on the body) ${ }^{28}$ are characteristic of the acute phase of schistosomiasis and are similar to the clinical condition of other parasitic diseases. This representation of symptoms common to neglected tropical diseases was also perceived in Pernambuco, Brazil. ${ }^{50}$

Some authors have reported people with little knowledge about the symptoms of schistosomiasis or even who have not been able to speak about the manifestations of the disease in the organism. ${ }^{20,46}$ We did not find total ignorance about schistosomiasis, but we observed that sometimes people identified the disease only by its severe form because these people spoke of the increase in size of the belly as the cause of schistosomiasis. However, other parasitic diseases can also lead to enlargement of the abdomen.

Symptoms that are common to various parasitic diseases cause confusion, and people cannot recognize if they have schistosomiasis. As the symptoms of the acute phase are not serious, people may be less concerned about health and do not seek medical assistance, contributing to the evolution of the disease. Gazzinelli et al. ${ }^{28}$ reported that in the understanding of individuals from the rural endemic area of Minas Gerais, Brazil, schistosomiasis was not considered an important public health problem because mild symptoms did not affect the activities developed by the population.

On the transmission of schistosomiasis, we noticed that our interviewees frequently cited the elements "water and snail." The analysis of discourse of schistosomiasis-positive patients in Santa Amélia (Paraná, Brazil) recorded a high frequency for the central idea that "Schistosomiasis is a disease that gets through the water" and "Schistosomiasis is a transmitted disease by the snail." 51

In Pernambuco, Brazil, the community also did not know the forms of transmission of schistosomiasis but related the infection always to water or to snails. ${ }^{50}$ It was observed also these individuals confused the vector snail with Pomacea sp. (snail that does not participate in the cycle of S. mansoni and is popularly known as "aruá" in Sao Bento, Maranhão). Researchers also reported that communities in Kenya had a wrong knowledge about the transmission cycle of various parasites. $^{29}$

In addition to the lack of understanding about the transmission of schistosomiasis, there are limitations in understanding the treatment of schistosomiasis. The treatment does not prevent reinfection, and therefore, it is necessary to identify the risk factors of schistosomiasis to make the control strategies more effective. ${ }^{39,52,53}$ It is also important that education activities focus on both infection prevention and the risk of reinfection. It is necessary to explain that medicine does not prevent the individual from being contaminated again by the worm. ${ }^{53,54}$

Socioeconomic vulnerability and determining factors for the establishment of schistosomiasis are not always perceived and understood by subjects living in areas at risk. This limitation in the understanding is a consequence of the low educational level. ${ }^{28,55}$ Thus, the perception of the health professional emphasizes that in addition to the improvements in chemo, sanitation, and health education, the control of schistosomiasis is only possible if the local context is considered. It is evident that for São Bento, it is necessary to create more possibilities of employment and to invest in the access and quality of basic education.

Through these interviews, it was noticed that both schools depend on the health department to develop action to control schistosomiasis. However, it is necessary to understand the school as health agencies and teachers as health promoters because this is an appropriate environment for preventive actions. $^{56}$ Education in the school environment is very important because the students are usually motivated to adopt preventive measures and the information acquired by these students can even reach other members of the family. ${ }^{17,57}$

The promotion of knowledge about health education in the school environment is also important to minimize possible limitations related to activities directed to adults, especially males. Men tend not to participate in educational campaigns because these campaigns are usually targeted to women or because they are held during work hours. ${ }^{40}$

Despite the limitations and great effort required to carry out health education activities, these campaigns are very important and, when associated with other control measures, show positive results with the reduction in the prevalence of schistosomiasis in the communities. ${ }^{29,32}$

Health and environmental education are not provided in São Bento, although it could promote disease prevention and enable people to improve their living conditions. According to Vasconcelos et al., ${ }^{57}$ developing connections between medical action, public awareness, and individuals' daily activities should be the aim of the health sector, which is responsible for prevention.

Consequently, educational programs on schistosomiasis are effective in improving people's knowledge about the disease. Popular health education, though, needs to be creative and transformative. ${ }^{58,59}$ As Ramos et al. ${ }^{60}$ demonstrate, the importance of such work should not be viewed from the perspective of formal education; learning happens on a continual basis, and information and knowledge empower people.

It is important to emphasize that the didactic materials used in health education proposals should be carefully elaborated to generate correct knowledge about schistosomiasis. On this, some researchers suggest that the development of didactic materials should follow the following steps: investigation of perceptions, attitudes, and practices of the population. ${ }^{61} \mathrm{We}$ emphasize that educational materials produced and distributed by the Unified Health System must present complete and coherent information so that the community adopts preventive attitudes and health promotion occurs. ${ }^{62}$ 
In addition to other measures, the control of schistosomiasis in this region depends on people accepting and understanding that they are themselves part of the disease cycle. Recognizing oneself as a participant in the man-diseaseenvironment process is a crucial step in behavioral changes that contribute to the control of both schistosomiasis and other parasitic diseases.

We also observed that the "flooded fields" need to be valued because of their importance to the local community. Recognizing oneself as part of the "flooded fields" and valuing the history and culture of this environment can result in improvements in the quality of life, self-esteem, and preservation of this ecosystem. This can be achieved through interdisciplinary work that ensures community participation in not only gathering information but also using the resultant knowledge acquired.

Received April 9, 2018. Accepted for publication June 14, 2020.

Published online July 20, 2020.

Note: Supplemental tables appear at www.ajtmh.org.

Acknowledgment: We thank the Laboratório de Parasitologia Humana (LPH) of the Universidade Estadual do Maranhão.

Financial support: This scientific work had financial support from the Fundação de Amparo a Pesquisa e ao Desenvolvimento Científico do Maranhão (FAPEMA).

Authors' addresses: Andressa Isabela Ferreira da Silva, Selma Patrícia Diniz Cantanhede, Jessica Oliveira Sousa, Renata Martins Lima, Nêuton Silva-Souza, Raimunda Nonata Fortes Carvalho-Neta, Zafira da Silva de Almeida, Débora Martins Silva Santos, Alcina Vieira de Carvalho Neta, and Ilka Márcia Ribeiro de Souza Serra, Departamento de Biologia, Universidade Estadual do Maranhao, Sao Luis, Brazil, E-mails: ddca12@hotmail.com, patriciasdc@yahoo.com.br, jes_sy quinha@hotmail.com, renatam_lima@hotmail.com, neuton@cecen.uema.br, raifortes@gmail.com, zafiraalmeida@gmail.com, debsan70@gmail.com, alcinavcn@yahoo.com, and ilka.tt@gmail.com. Lígia Tchaicka, Departamento de Química e Biologia, Universidade Estadual do Maranhao, Sao Luis, Brazil, E-mail: Itchaicka@yahoo.com.br.

\section{REFERENCES}

1. Mutapi F, Maizels R, Fenwick A, Woolhouse M, 2017. Human schistosomiasis in the post mass drug administration era. Lancet Infect Dis 17: e42-e48.

2. World Health Organization, 2014. Schistosomiasis Fact Sheet Number 115. Geneva: Switzerland: WHO. Available at: http:// www.who.int/mediacentre/factsheets/fs115/en/. Accessed January 24, 2018.

3. Barakat RMR, 2013. Epidemiology of schistosomiasis in Egypt: travel through time. J Adv Res 4: 425-432.

4. Lai YS et al., 2015. Spatial distribution of schistosomiasis and treatment needs in sub-Saharan Africa: a systematic review and geostatistical analysis. Lancet Infect Dis 15: 927-940.

5. Ministério da Saúde, 2017. Secretaria de Vigilância em Saúde. Coordenação-Geral de Desenvolvimento da Epidemiologia em Serviços, Vol. 1. Brasilia, Brazil: Guia de Vigilância em Saúde, 752. Available at: https://bvsms.saude.gov.br/bvs/publicacoes/ guia_vigilancia_saude_3ed.pdf. Accessed March 3, 2020.

6. Martins-Melo FR, Pinheiro MCC, Ramos AN, Jr., Alencar CH, Moraes Bezerra FS, Heukelbach J, 2014. Trends in schistosomiasis-related mortality in Brazil, 2000-2011. Inter $J$ Parasitol 44: 1055-1062.

7. Barbosa CS, Souza Gomes EC, Campos JV, Oliveira FJM, Silva Mesquita MC, Oliveira ECA, Domingues ALC, 2016. Morbidity of mansoni schistosomiasis in Pernambuco-Brazil: analysis on the temporal evolution of deaths, hospital admissions and severe clinical forms (1999-2014). Acta Trop 164: 10-16.

8. Costa CS, Rocha AM, Silva GS, Jesus RPFS, Albuquerque AC, 2017. Programa de Controle da Esquistossomose: avaliação da implantação em três municípios da Zona da Mata de Pernambuco, Brasil. Saúde Debate 41: 229-241.

9. Ferreira LA, Lima FL, Anjos MR, Costa JML, 1998. Forma tumoral encefálica esquistossomótica: apresentação de um caso tratado cirurgicamente. Rev Soc Bras Med Trop 31: 89-93.

10. David NF, Cantanhede SPD, Monroe NB, Pereira LPLA, SilvaSouza N, Abreu-Silva AL, Oliveira VM, Tchaicka L, 2018. Spatial distribution and seasonality of Biomphalaria spp. in São Luís (Maranhão, Brazil). Parasitol Res 117: 1495-1502.

11. Costa-Neto JP, Barbieri R, Ibañez MSR, Cavalcante PRS, Piorski NM, 2002. Limnologia de três ecossistemas aquáticos característicos da Baixada Maranhense. Bol Lab Hidrobiol 14: 19-38.

12. Pereira YNO, Veloso CA, Costa PA, Mineiro MJC, Silva TC, 2010. Parasitoses da Baixada Ocidental Maranhense. Rev Saud 4: 89.

13. Lira MGS, Miranda GS, Rodrigues JGM, Nogueira RA, Gomes GCC, Cantanhêde LG, Silva-Souza N, 2016. Aspectos biológicos de Holochilus sp., hospedeiro natural da esquistossomose. Ciênc Anim Bras 17: 143-153.

14. Miranda GS, Rodrigues JGM, Lira MGS, Nogueira RA, Gomes GCC, Silva-Souza N, 2015. Monitoramento de positividade para Schistosoma mansoni em roedores Holochilus sp. naturalmente infectados. Ciênc Anim Bras 16: 456-463.

15. Nogueira RA, Lira MGS, Miranda GS, Rodrigues JGM, Gomes GCC, Silva-Souza N, 2016. Distribuição dos moluscos transmissores da esquistossomose no município endêmico de São Bento, Maranhão, Brasil. Rev Pat Trop 45: 295-304.

16. Cantanhede SPD, Fernandez MA, Mattos ACD, Montresor LC, Silva-Souza N, Thiengo SC, 2014. Freshwater gastropods of the Baixada Maranhense Microregion, an endemic area for schistosomiasis in the State of Maranhão, Brazil: i-qualitative study. Rev Soc Bras Med Trop 47: 79-85.

17. Musuva RM, Awiti A, Omedo M, Ogutu M, Secor WE, Montgomery SP, Alaii J, Mwinzi PNM, 2014. Community knowledge, attitudes and practices on schistosomiasis in western Kenya-the SCORE project. Am J Trop Med Hyg 90: 646-652.

18. Omedo MO, Matey EJ, Awiti A, Ogutu M, Alaii J, Karanja DM, Montgomery SP, Secor WE, Mwinzi PN, 2012. Community health workers' experiences and perspectives on mass drug administration for schistosomiasis control in western Kenya: the SCORE Project. Am J Trop Med Hyg 87: 1065-1072.

19. Uchoa E, Barreto SM, Firmo JO, Guerra HL, Pimenta FG Jr., Lima e Costa MF, 2000. The control of schistosomiasis in Brazil: an ethno-epidemiological study of the effectiveness of a community mobilization program for health education. Soc Sci Med 51: 1529-1541.

20. Nyati-Jokomo Z, Chimbari MJ, 2017. Risk factors for schistosomiasis transmission among school children in Gwanda district, Zimbabwe. Acta Trop 175: 84-90.

21. Zhou LY, Deng Y, Steinmann P, Yang K, 2013. The effects of health education on schistosomiasis japônica prevalence and relevant knowledge in the People's Republic of China: a systematic review and meta-analysis. Parasitol Int 62: 150-156.

22. Luz ZMP, Pimenta DN, Rabello A, Schall VT, 2003. Evaluation of informative materials on leishmaniasis distributed in Brazil: criteria and basis for the production and improvement of health education materials. Cad Saude Publica 19: 561-569.

23. Fleming FM, Fenwick A, Tukahebwa EM, Lubanga RGN, Namwangye H, Zaramba S, Kabatereine NB, 2009. Process evaluation of schistosomiasis control in Uganda, 2003 to 2006: perceptions, attitudes and constraints of a national programme. Parasitology 136: 1759-1769.

24. Instituto Brasileiro de Geografia e Estatística (BRASIL), 2011. Censo Demográfico 2010. Características da população e dos domicilios: resultados do universo. Rio de Janeiro, Brazil: IBGE. Available at: https://biblioteca.ibge.gov.br/visualizacao/periodicos/93/cd_2010_ caracteristicas_populacao_domicilios.pdf. Accessed January 21, 2020.

25. Minayo MCS, 2010. O Desafio do conhecimento: pesquisa qualitativa em saúde. O desafio do conhecimento: pesquisa qualitativa em saúde, 11th edition. São Paulo, Brazil: Hucitec.

26. Yin RK, 2015. Estudo de Caso: Planejamento e métodos, 5th edition. Porto Alegre, Brazil: Bookman Editora. 
27. Bardin L, 2006. Análise de conteúdo. Lisboa, Portugal: Edições, 70.

28. Gazzinelli A, Gazzinelli MF, Cadete MM, Pena Filho S, Sá IR, Kloos $\mathrm{H}, 1998$. Sociocultural aspects of Schistosomiasis mansoni in an endemic area in Minas Gerais, Brazil. Cad Saúde Pública 14: 841-849.

29. Masaku J, Mwende F, Odhiambo G, Musuva R, Matey E, Kihara JH, Thuita IG, Njomo DW, 2017. Knowledge, practices and perceptions of geo-helminthes infection among parents of preschool age children of coastal region, Kenya. PLoS Negl Trop Dis 11: e0005514.

30. Edogiawerie D, Turay AA, Okpala HO, 2016. Prevalence of intestinal helminthes among primary school children in Ihumudumu community, Ekpoma, Edo, Nigeria. Inter J Comm Res 5: $12-21$.

31. Adedeji AS, Okechukwu O, Adenike OF, Abolore AH, Kayode OS, Kayode OG, 2017. Prevalence and risk factors of schistosomiasis infection among primary school pupils in Patigi local government area, Kwara State, Nigeria. Sudan Med Jour 53: $1-13$.

32. Moza PG, Pieri OS, Barbosa CS, Rey L, 1998. Fatores sóciodemográficos e comportamentais relacionados à esquistossomose em uma agrovila da zona canavieira de Pernambuco, Brasil. Cad Saúde Pública 14: 107-115.

33. Abou-el-Naga IF, 2015. Demographic, socioeconomic and environmental changes affecting circulation of neglected tropical diseases in Egypt. Asian Pac J Trop Biomed 8: 881-888.

34. Patz JA, Graczyk TK, Geller N, Vittor AY, 2000. Effects of environmental change on emerging parasitic diseases. Int $J$ Parasitol 30: 1395-1405.

35. Melo AGS, Melo CM, Oliveira CCC, Oliveira DS, Santos VB, Jeraldo VLS, 2011. Esquistossomose em área de transição rural-urbana: reflexões epidemiológicas. Cienc Cuid Saude 10: 506-513.

36. Paredes H, Souza-Santos R, Resendes APC, Souza MAA, Albuquerque J, Bocanegra S, Gomes EC, Barbosa CS, 2010. Spatial pattern, water use and risk levels associated with the transmission of schistosomiasis on the north coast of Pernambuco, Brazil. Cad Saúde Pública 26: 1013-1023.

37. Cunha LDA, Guedes SAG, 2012. Prevalência de esquistossomose mansônica na cidade de Nossa Senhora do Socorro. Ideias Inovação 1: 41-48.

38. Sousa AL et al., 2013. Morfofisiologia, Biologia e Conservação de Jurará (Kinosternon scorpioides) em habitat natural na cidade de São Bento-Baixada Maranhense. AlmeidaZS, org. Sumário Executivo para plano de ação na área de proteção ambiental da Baixada Maranhense. Maranhão, Brazil: Colorgraf.

39. Vidal LM, Barbosa AS, Ribeiro RMC, Silva LWS, Vilela ABA, Prado FO, 2011. Considerações sobre esquistossomose mansônica no município de Jequié, Bahia. Rev Patol Trop 40: 367-382.

40. Gomes ACL, Galindo JM, Lima NND, Silva ÉVGD, 2016. Prevalência e carga parasitária da esquistossomose mansônica antes e depois do tratamento coletivo em Jaboatão dos Guararapes, Pernambuco. Epidemiol Serv Saúde 25: 243-250.

41. Ferreira Barreto M, Soares de Freitas MDC, 2017. Segurança alimentar e nutricional e contaminação ambiental: tabu e estigma. Ciênc Saúde Coletiva 22: 527-534.

42. Gazzinelli MF, Gazzinelli A, Santos RV, Gonçalves LAO, 2002. A interdição da doença: uma construção cultural da esquistossomose em área endêmica, Minas Gerais, Brasil. Cad Saúde Públ 18: 1629-1638.

43. Oliveira TF, Soares MS, Cunha RA, Monteiro S, 2008. Educação e controle da esquistossomose em Sumidouro (RJ, Brasil): avaliação de um jogo no contexto escolar. Rev Bras Pesq Educ Ciênc 8. Available at: https://https://periodicos.ufmg.br/ index.php/rbpec/article/view/4012/2576. Accessed January $21,2020$.

44. Cruz PTR, Araújo HL, 2014. Estigma ou Preconceito? Uma análise crítica da Súmula 443 do TST à luz da condição jurídica do empregado portador do vírus HIV ou de outra doença grave. Rev Pensar Direito 5: 1-18. Available at: http://http:// revistapensar.com.br/direito/pasta_upload/artigos/a217.pdf. Accessed January 21, 2020.

45. Pinheiro LBC, de Sousa Lima F, Rocha TT, Tavares-Martins ACC, 2016. Ressignificação das concepções de Natureza, Meio
Ambiente e Educação Ambiental através de uma trilha ecológica. Rev Bras Educ Amb 11: 196-214.

46. Odhiambo GO, Musuva RM, Atuncha VO, Mutete ET, Odiere MR, Onyango RO, Alaii JA, Mwinzi PN, 2014. Low levels of awareness despite high prevalence of schistosomiasis among communities in Nyalenda informal settlement, Kisumu city, western Kenya. PLoS Negl Trop Dis 8: e2784.

47. Maseko TS, Mkhonta NR, Masuku SK, Dlamini SV, Fan CK, 2016. Schistosomiasis knowledge, attitude, practices, and associated factors among primary school children in the Siphofaneni area in the Lowveld of Swaziland. J Microbiol Immunol Infect 51: 103-109.

48. Santos L, Nogueira M, Rezende C, Ferreira R, 2017. Doenças negligenciadas no município de Sabará: casos, portadores e percepções. Arq Ciênc Saúde UNIPAR 21: 155-162.

49. Sow S, Vlas SJ, Mbaye A, Polman K, Gryseels B, 2013. Low awareness of intestinal schistosomiasis in northern Senegal after 7 years of health education as part of intense control and research activities. Trop Med Int Health 8: 744-749.

50. Silva DCG, 2005. Esquistossomose Mansônica: aspectos sócioculturais em comunidades rural e urbana de Pernambuco. Master Dissertation, Mestrado em Saúde Pública, Fundação Oswaldo Cruz, Recife, Brazil. Available at: http://www. cpqam.fiocruz.br/bibpdf/2005silva-dcg.pdf. Accessed January $30,2020$.

51. Otenio MH, Pereira JA, Otenio CCM, Melo SCCS, Lefèvre AMC, Lefèvre FO, 2010. Conhecimento da esquistossomose para pacientes positivos. HU Revista 36: 123-130.

52. Noronha CV, Barreto ML, Silva TM, Souza IM, 1995. Uma concepção popular sobre a esquistossomose mansônica: os modos de transmissão e prevenção na perspectiva de gênero. Cad Saúde Públ 11: 106-117.

53. Mbanefo CE, Huy NT, Wadagni AA, Eneanya Cl, Nwaorgu O, Hirayama K, 2014. Host determinants of reinfection with schistosomes in humans: a systematic review and meta-analysis. PLoS Negl Trop Dis 8: e3164.

54. Gazzinelli A, Oliveira-Prado R, Matoso LF, Veloso BM, Andrade G, Kloos H, Bethony JM, Assunção RM, Correa-Oliveira R, 2017. Schistosoma mansoni reinfection: analysis of risk factors by classification and regression tree (CART) modeling. PLoS One 12: e0182197.

55. Muhumuza S, Kitimbo G, Oryema-Lalobo M, Nuwaha F, 2009. Association between socio economic status and schistosomiasis infection in Jinja district, Uganda. Trop Med Int Health 14: 612-619.

56. Monroe NB, Leite PRR, Santos DN, Sá-Silva JR, 2013. O Tema transversal saúde e o ensino de ciências: representações sociais de professores sobre as parasitoses intestinais. Investigações Ensino Ciências 18: 7-22. Available at: https:// www.if.ufrgs.br/cref/ojs/index.php/ienci/article/view/146/101. Accessed April 3, 2020.

57. Vasconcelos EM, 1998. Educação popular como instrumento de reorientação das estratégias de controle das doenças infecciosas e parasitárias. Cad Saúde Pública 14: 39-57.

58. Reis INC, Silva ILR, Un JAW, 2014. Public space in primary health care: popular education and health promotion at Brazilian health-school centers. Interface 18: 1161-1174.

59. Ribeiro PJ, Aguiar LAK, Toledo CF, Barros SMO, Borges DR, 2004. Educational program in schistosomiasis: a model for a methodological approach. Rev Saúde Púb/ 38: 415-421.

60. Ramos MC, Silva DC, Cunha e Silva SL, 2007. Educação, saúde e meio ambiente: o caso da esquistossomose no município de Itororó-BA. Rev Saúde.Com 3: 70-76. Available at: http:// periodicos2.uesb.br/index.php/rsc/article/view/111/82. Accessed April 3, 2020.

61. Murta FLG, Modena CM, Carvalho OS, Massara CL, 2014. Abordagem sobre esquistossomose em livros de ciências e biologia indicados pelo programa nacional do livro didático (PNLD)-2011/2012. Rev Patol Trop 43: 195-208.

62. Massara CL, Murta FLG, Enk MJ, Araújo ADD, Modena CM, Carvalho ODS, 2016. Caracterização de materiais educativos impressos sobre esquistossomose, utilizados para educação em saúde em áreas endêmicas no Brasil. Epidemio/Serv Saúde 25: 575-658. 